\title{
ANALISIS PERBANDINGAN ONLINE DAN OFFLINE TRAINING PADA JARINGAN BACKPROPAGATION PADA KASUS PENGENALAN HURUF ABJAD
}

\author{
M Anggi Rivai Nst, Muhammad Zarlis, Zakarias Situmorang \\ Program Studi S-2 Teknik Informatika USU \\ anggi.rivai.nst@gmail.com
}

\begin{abstract}
Abstrak- Penelitian ini dibuat untuk pembelajaran tentang model jaringan syaraf tiruan yaitu Backpropagation, dimana didalamnya terdapat metode pembelajaran-pembelajaran yang bermanfaat untuk kita ketahui dalam identifikasi masalah sehingga dapat mempelajari model dengan sendirinya dengan memiliki langkah-langkah yang telah kita berikan. Ada dua metode dari model Backpropagation dalam melakukan pembelajaran berupa pelatihan-pelatihan secara langsung(Online) dan secara tidak langsung(Offline). Dengan membandingkan kedua metode ini maka analisis dari pengenalan huruf abjad akan mudah didapat berdasarkan titik-titik yang dimiliki tiap iterasi yang ada. Dengan melakukan perbandingan kedua metode ini kita juga dapat mengetahui dimana perbedaan yang didapat sehingga kita dapat mengetahui dengan baik yang mana sebaiknya kita gunakan dalam proses melakukan perkenalan huruf abjad. Berdasarkan perbandingan yang dibuat bukan hanya untuk melakukan perbandingan yang baik atau buruk tetapi untuk pembelajaran tentang akurasi dan waktu yang digunakan.
\end{abstract}

Kata Kunci - Jaringan Syaraf Tiruan, Backpropagation, Online, Offline.

\section{PENDAHULUAN}

Artificial Neural Network atau jaringan syaraf tiruan merupakan bidang yang sangat berkembang saat ini. Pemanfaatan teknologi mesin dan computer yang tidak terbatas sebagai alat bantu dalam aktifitas manusia mendorong penelitian secara besar-besaran terhadap kecerdasan buatan atau artificial intelligence. Mesin yang selama ini hanya bekerja sesuai dengan instruksi yang ditentukan diharapkan mampu bekerja dan mengambil keputusan sekaligus layaknya manusia(Parker, 2006).

Identifikasi dan klasifikasi merupakan kegiatan menggolongkan objek kedalam kategori tertentu untuk tujuan - tujuan tertentu. Kegiatan identifikasi dan klasifikasi yang membutuhkan pengetahuan dan intuisi manusia dapat digantikan oleh mesin sehingga dapat meningkatkan kecepatan dalam kegiatan produksi pada beberapa bidang industri maupun kecepatan pengolahan data pada bidang bidang lain. Jaringan syaraf tiruan merupakan model matematika yang meniru cara kerja syaraf manusia sehingga computer atau mesin dapat belajar dari data yang diberikan dan memberikan output yang ditentukan. Mesin yang telah dilengkapi dengan jaringan syaraf tiruan dapat belajar terhadap lingkungan yang diberikan dan mampu melakukan kegiatan yang selama ini masih dilakukan oleh manusia yaitu mengambil keputusan terhadap identifikasi maupun klasifikasi.

Backpropagation merupakan salah satu model dari jaringan syaraf tiruan, dimana Backpropagation menggunakan beberapa lapisan yang terdiri dari lapisan input, hidden dan output (Hermawan, 2006). Tiap lapisan terdiri dari node node yang saling terhubung dan tiap hubungan diberikan bobot.

Jaringan Backpropagation merupakan metode yang banyak digunakan dalam proses identifikasi dan proses klasifikasi karena kemampuannya dalam mempelajari beberapa kelas sekaligus melalui proses propagasi balik.

Backpropagation merupakan metode yang sangat baik dalam proses pengenalan mengingat kemampuannya dalam mengadaptasikan kondisi jaringan dengan data yang diberikan dengan proses pembelajaran (Hermawan, 2006). Proses pembelajaran jaringan syaraf tiruan terbagi menjadi dua jenis yaitu pembelajaran Onlinedan Offline. Pembelajaran Online merupakan pembelajaran dimana proses perbaikan bobot dilakukan pada tiap sample data yang dilatih pada tiap iterasi sedangkan pembelajaran Offline melakukan perbaikan bobot jaringan menggunakan error dari seluruh sample data (Duffner \& Garcia, 2007). Pembelajaran Online maupun Offline memiliki kelebihan dan kelemahan tersendiri. Beberapa penelitian menilai pembelajaran Onlinelebih baik daripada pembelajaran Offline, beberapa penelitian lain mengatakan sebaliknya (Lemme, 2010), (Singh, 2012), (Sha \& Bajic, 2000). 
Secara teoritis pembelajaran Offline memberikan performa yang lebih baik daripada pembelajaran Online, dimana pembelajaran Offline memberikan kecepatan belajar yang lebih baik dibandingkan dengan pembelajaran Online. Sistem nyata atau real time system yang menggunakan data actual atau data terus berkembang dan bervariasi membuat pembelajaran Offline menjadi pembelajaran yang tidak efektif, dan pada kasus ini Online training memberikan kinerja yang lebih baik dibandingkan dengan pembelajaran Offline(LeCun, 1998)(Istook, 2003).

\section{TINJAUAN PUSTAKA}

\section{A. Jaringan syaraf Tiruan}

Model saraf ditunjukkan dengan kemampuannya dalam emulasi, analisis, prediksi dan asosiasi. Kemampuan yang dimiliki JST dapat digunakan untuk belajar dan menghasilkan aturan atau operasi dari beberapa contoh atau input yang dimasukkan dan membuat prediksi tentang kemungkinan output yang akan muncul atau menyimpan karakteristik dari input yang disimpan kepadanya. Jaringan syaraf merupakan sebuah kelompok pengolahan elemen dalam suatu kelompok yang khusus membuat perhitungan sendiri dan memberikan hasilnya kepada kelompok kedua atau berikutnya.Setiap sub-kelompok menurut gilirannya harus membuat perhitungan sendiri dan memberikan hasilnya untuk subgrup atau kelompok yang belum melakukan perhitungan. Pada akhirnya sebuah kelompok dari satu atau beberapa pengolahan elemen tersebut menghasilkan keluaran (output) dari jaringan.

Setiap pengolahan elemen membuat perhitungan berdasarkan pada jumlah masukan (input). Sebuah kelompok pengolahan elemen disebut layer atau lapisan dalam jaringan. Lapisan pertama adalah input dan yang terakhir adalah output. Lapisan di antara lapisan input dan output disebut dengan lapisan tersembunyi (hidden layer). Jaringan sayaraf tiruan merupakan suatu bentuk arsitektur yang terdistribusikan paralel dengan sejumlah besar node dan hubungan antar-node tersebut. Tiap titik hubungan dari satu node ke node yang lain mempunyai harga yang diasosiasikan dengan bobot. Setiap node memiliki suatu nilai yang diasosiasikan sebagai nilai aktivasi node.

\section{B. Backpropagation}

Sebuah jaringan Backpropagation sederahana terdiri dari sebuah input dan output layer. Input pada input layer diteruskan melalui bobot untuk membawa input menuju lapisan output (Muijrers, 2011). Jaringan perambatan galat mundur terdiri atas tiga lapisan atau lebih unit pengolah.Ketiga lapisan tersebut terhubung secara penuh.Perambatan galat maju dimulai dengan memberikan pola masukan ke lapisan masukan.Pola masukan ini merupakan nilai aktivasi unit-unit masuka.Dengan melakukan perambatan maju dihitung nilai aktivasi pada unitunit di lapisan berikutnya.Pada setiap lapisan, tiap unit pengolah melakukan penjumlahan berbobot dan menerapkan fungsi sigmoid untuk menghitung keluarannya.

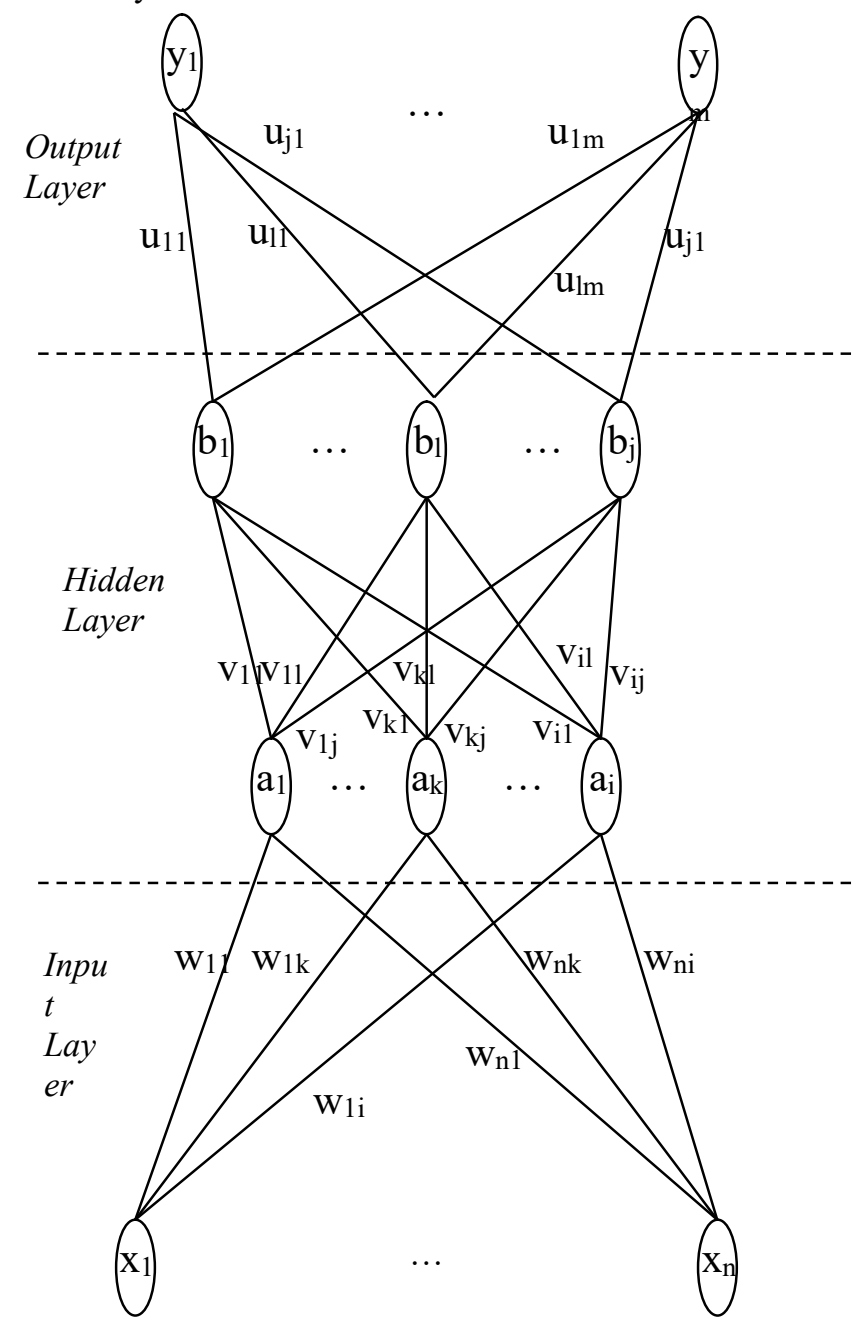

Gbr 1 Arsitektur Multilayer Neural Network Sumber : Hermawan, A

Algoritma selengkapnya elatihan jaringan Backpropagation adalah sebagai berikut (Hermawan, 2006) :

Langkah $0 \quad$ :Inisialisasi bobot (ambil bobot awal dengan nilai random yang cukup kecil).

Langkah 1 :Bila syarat berhenti adalah salah, kerjakan langkah 2 sampai

Langkah 2 :Untuk setiap pasangan pelatihan, kerjakan langkah 3-8. 


\section{Feedforward:}

Langkah 3 : Tiap-tiap unit input $\left(\mathrm{X}_{\mathrm{i}}, \mathrm{i}=1,2,3, \ldots, \mathrm{n}\right)$ menerima sinyal $\mathrm{x}_{\mathrm{i}}$ dan meneruskan sinyal ke semua unit pada lapisan hidden (lapisantersembunyi).

Langkah 4 : Tiap-tiap unit lapisan tersembunyi ( $\mathrm{Zj}$, $\mathrm{j}=1,2,3, \ldots, \mathrm{p})$ menjumlahkansinyal-sinyal input terbobot:

$$
\mathrm{z}_{-} \mathrm{in}_{\mathrm{j}}=\mathrm{v}_{0 \mathrm{j}}+\sum_{i=1}^{n} x_{i} v_{i j}
$$

$\mathrm{v}=$ Bobot awal input ke hidden .

Gunakan fungsi aktivasi untuk menghitung sinyal outputnya:

$$
\mathrm{z}_{\mathrm{j}}=\mathrm{f}\left(\mathrm{z}_{-} \mathrm{in}_{\mathrm{j}}\right)
$$

dan mengirimkan sinyal tersebut ke semua unit di lapisan atasnya (unit unit output).

Langkah 5 : Tiap-tiap output $\left(\mathrm{Y}_{\mathrm{k}}, \mathrm{k}=1,2,3, \ldots, \mathrm{m}\right)$ menjumlahkan sinyal-sinyal input terbobot.

$$
\mathrm{y}_{-} \mathrm{in}_{\mathrm{k}}=\mathrm{w}_{0 \mathrm{k}}+\sum_{j=1}^{p} z_{j} w_{j k}
$$

gunakan fungsi aktivasi untuk menghitung sinyal outputnya:

$$
\mathrm{y}_{\mathrm{k}}=\mathrm{f}\left(\mathrm{y}_{-} \mathrm{in}_{\mathrm{k}}\right)(2.4)
$$

dan kirimkan sinyal tersebut ke semua unit di lapisan hidden (lapisan tersembunyi).

Catatan: Langkah (b) dilakukan sebanyak jumlah lapisan tersembunyi.

\section{Backpropagation}

Langkah 6 : Tiap-tiap unit output $\left(\mathrm{Y}_{\mathrm{k}}\right.$, $\mathrm{k}=1,2,3, \ldots, \mathrm{m})$ menerima target pola yangberhubungan dengan pola input pembelajaran, hitung informasi errornya

$$
\delta_{\mathrm{k}}=\left(\mathrm{t}_{\mathrm{k}}-\mathrm{y}_{\mathrm{k}}\right) \mathrm{f}^{\prime}\left(\mathrm{y} \_\mathrm{i} \mathrm{n}_{\mathrm{k}}\right)(2.5)
$$

Kemudian hitung koreksi bobot (yang nantinya akan digunakanuntuk memperbaiki nilai $\mathrm{w}_{\mathrm{jk}}$ ):

$$
\Delta \mathrm{w}_{\mathrm{jk}}=\alpha \delta_{\mathrm{k}} \mathrm{Z}_{\mathrm{j}}(2.6)
$$

Hitung juga koreksi bias

$$
\Delta \mathrm{w}_{0 \mathrm{k}}=\alpha \delta_{\mathrm{k}}(2.7)
$$

Langkah 7 : Tiap-tiap unit lapisan tersembunyi ( $\mathrm{Zj}$, $\mathrm{j}=1,2,3, \ldots, p$ ) menjumlahkandelta inputnya (dari unit-unit yang berada dilapisan hidden).

$$
\delta \operatorname{in}_{\mathrm{j}}=\sum_{k=1}^{m} \delta_{k} w_{j k}
$$

Kalikan nilai ini dengan turunan dari fungsi aktivasi untuk menghitung informasi error:

$$
\delta_{\mathrm{j}}=\delta \delta_{-} \mathrm{in}_{\mathrm{j}} \mathrm{f}^{\prime}\left(\mathrm{z}_{-} \mathrm{in}_{\mathrm{j}}\right)(2.9)
$$

kemudian hitung koreksi bobot:

$$
\Delta \mathrm{v}_{\mathrm{ij}}=\alpha \delta_{\mathrm{j}} \mathrm{x}_{\mathrm{i}}(2.10)
$$

Langkah 8 : Tiap-tiap unit ouput $\left(\mathrm{Y}_{\mathrm{k}}, \mathrm{k}=1,2,3, \ldots, \mathrm{m}\right)$ memperbaiki bias dan bobotnya $(\mathrm{j}=1,2,3, \ldots, \mathrm{p})$ :

$$
\mathrm{w}_{\mathrm{jk}}(\text { baru })=\mathrm{w}_{\mathrm{jk}}(\text { lama })+\Delta \mathrm{w}_{\mathrm{jk}}(2.11)
$$

Tiap-tiap unit lapisan tersembunyi $(\mathrm{Zj}, \mathrm{j}=1,2,3, \ldots, \mathrm{p})$ memperbaiki nilai bias dan bobotnya (i=1,2,3,...,n.):

$\mathrm{v}_{\mathrm{ijj}}($ baru $)=\mathrm{v}_{\mathrm{ijj}}(\mathrm{lama})+\Delta \mathrm{v}_{\mathrm{ij}}(2.12)$

Langkah 9 : Uji syarat berhenti.

\section{OnlineBackpropagation}

OnlineBackpropagation merupakan jaringan Backpropagation yang menggunakan proses update secara Online. Online dimaksudkan setiap perubahan bobot dilakukan pada setiap sample atau pada setiap input. Pelatihan dimulai dengan memasukkan nilai input dan melakukan perambatan maju, error kemudian dikalkulasi dan update bobot baru langsung diterapkan untuk input tersebut. Proses update bobot dilakukan untuk setiap varian input (Istook, 2003).

Backpropagation mungkin algoritma pembelajaran yang paling popular, algoritma untuk perceptron multilayer merupakan jenis arsitektur jaringan saraf yang sederhana dan efekif. Ini adalah metode backpropagtion secara Online dengan tingkat adaptif pembelajaran secara global yang didasari oleh ide yang disebut sudut tingkat peringatan yang di inisiasikan. Dengan nilai yang sangat kecil dan ditambah atau di kurangi sesuai dengan evolusi criteria kesalahan dari interiaksi terakhir.

Terdapat dua kelompok tingkat pembelajaran :

1. Mengacu kepada metode penyesuaian tingkat pembelajaran secara keseluruhan untuk seluruh jaringan.

2. Adaptasi secara independen tergantung tingkat masalah yang dihadapi.

\section{OfflineBackpropagation}

OfflineBackpropagation merupakan jaringan Backpropagation yang menggunakan proses update secara batch. Offline dimaksudkan setiap perubahan bobot dilakukan pada saat error dari tiap set diperoleh. Pelatihan dimulai dengan 
memasukkan nilai input dan melakukan perambatan maju, error kemudian ditampung dan disumarikan sampai pada sample input terakhir. Proses update bobot dilakukan berdasarkan error yang diperoleh dari semua set input (Istook, 2003).

Offline training dapat juga disebut sebagai batch training, dimana pelatihan dilakukan dengan error dari setiap sample input ditampung terlebih dahulu kemudian digunakan untuk proses update bobot pada saat semua sample telah dilatih. Beberapa kelebihan Offline training yaitu sebagai berikut (LeCun, 1998) :

- Kondisi dari konvergensi dapat dengan mudah dilacak dan dipelajari.

- Beberapa teknik peningkatan pembelajaran hanya bekerja pada Offline training.

- Analisis teori terhadap perubahan bobot dan konvergensi lebih mudah.

E. Klasifikasi Pada Jaringan Syaraf Tiruan

Jaringan syaraf tiruan merupakan bidang pengetahuan yang mana bertujuan untuk menciptakan mesin yang memiliki kecerdasan dan pemahaman dengan menerapkan simulasi dari system syaraf manusia (Cheriet, 2007). Sebuah jaringan syaraf tiruan terdiri dari beberapa neuron neuron yang saling terhubung satu sama lain.

Pada jaringan syaraf tiruan sebuah neuron sering juga disebut dengan sebuah unit atau sebuah node.Sebuah model neuron memiliki beberapa koneksi yang memiliki bobot, unit penjumlah dan sebuah fungsi aktivasi.

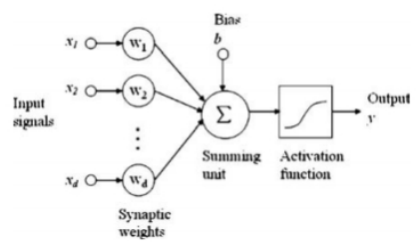

Gbr 2 Model dari sebuah jaringan neuron (Cheriet, 2007).

Jaringan syaraf tiruan mampu merekam pengetahuan yang direpresentasikan dengan bobot pada koneksi antar neuron. Proses pelatihan sebuah jaringan syaraf tiruan merupakan kegiatan memberikan sejumlah input pada jaringan sehingga jaringan memodifikasi bobot - bobot pada tiap koneksi neuronnya dalam rangka mempelajari input yang diberikan.

Jaringan syaraf yang telah mampu memahami input yang telah diberikan kemudian dapat digunakan untuk kegiatan identifikasi dan klasifikasi. Kemampuan jaringan syaraf dalam melakukan identifikasi dan klasifikasi tidak terlepas pada kemampuannya beradaptasi terhadap input yang diberikan dalam bentuk perubahan bobot pada koneksi antar neuron.

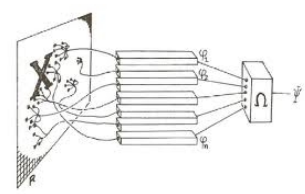

Gbr 3 Ilustrasi Klasifikasi Pola Menggunakan Jaringan Syaraf Tiruan (McClelland, 2013)

Kemampuan klasifikasi yang dimiliki oleh jaringan syaraf tiruan kemudian dimanfaatkan pada berbagai bidang seperti bidang identifikasi objek dan klasifikasi pola. Beberapa set objek diberikan kepada jaringan dalam proses pelatihan sehingga jaringan mampu mengenali dan mengidentifikasi objek - objek tersebut.

\section{ANALISIS DAN PERANCANGAN}

Langkah - langkah yang akan dilakukan dalam penelitian ini adalah

1. Persiapan karakter yang akan digunakan pada proses pelatihan Online dan Offline pada jaringan Backpropagation dalam bentuk format citra digital.

2. Perancangan jaringan Backpropagation yang akan digunakan pada penelitian.

3. Menentukan parameter bobot, bias dan target yang akan digunakan pada pelatihan Online dan Offline.

4. Melakukan pengamatan terhadap performa pembelajaran pada pelatihan Online dan Offline dari jaringan Backpropagation yang dibangun.

5. Melakukan analisa terhadap kecepatan pelatihan, perubahan gradien dan akurasi dari kedua jenis pelatihan.

Arsitektur jaringan syaraf tiruan Backpropagation yang akan digunakan pada penelitian ini dapat dilihat pada gambar berikut ini.

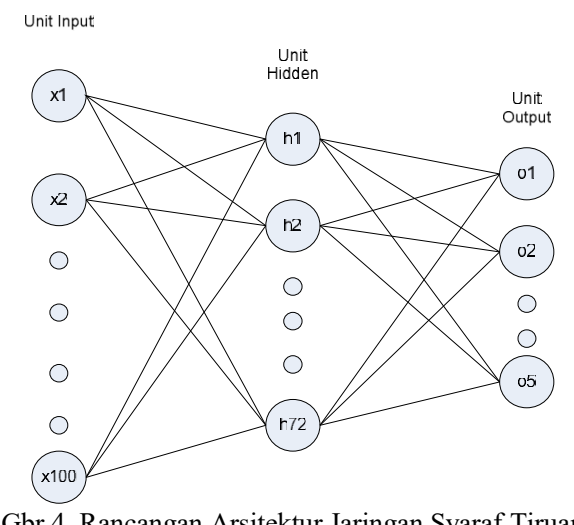

Karakter yang digunakan pada penelitian ini adalah karakter ' $A$ ' - ' $Z$ ' dengan jenis kapital seperti yang terlihat pada gambar berikut. 


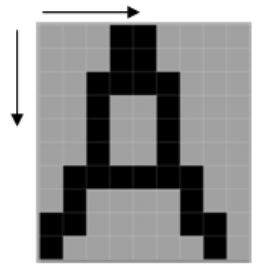

Gbr 5 Karakter Pelatihan

\section{A. Analisis Proses Pelatihan Offline}

Pelatihan Offline merupakan pelatihan jaringan saraf tiruan yang menganut konsep batch.Secara garis besar tahapan pelatihan pada jenis pelatihan Offline dapat dijabarkan sebagai berikut.

1. Baca nilai input dari data latih $\mathrm{ke}-\mathrm{n}$.

2. Teruskan nilai input ke unit input.

3. Teruskan nilai input yang diterima oleh unit input ke unit tersembunyi atau hidden.

4. Hitung nilai keluaran dari unit tersembunyi menggunakan nilai sinyal input terbobot menggunakan persamaan 2.2 dan melakukan perhitungan fungsi aktivasi untuk memperoleh nilai keluaran dari unit tersembunyi menggunakan persamaan 2.3.

5. Teruskan nilai keluaran dari unit tersembunyi ke unit output.

6. Hitung nilai keluaran dari unit output dengan menghitung nilai sinyal keluaran unit keluaran terbobot menggunakan persamaan 2.3 yang kemudian diikuti dengan menghitung nilai output menggunakan fungsi aktivasi menggunakan persamaan 2.4.

7. Hitung galat error untuk data latih $\mathrm{ke}-\mathrm{n}$ menggunakan persamaan 2.5 .

8. Hitung koreksi untuk tiap bobot pada lapisan tersembunyi menggunakan persamaan 2.6.

9. Hitung galat error pada unit tersembunyi menggunakan persamaan 2.9.

10. Hitung koreksi untuk tiap bobot pada lapisan input menggunakan persamaan 2.10 .

11. Lanjutkan tahap pelatihan untuk data latih $\mathrm{n}+1$.

12. Setelah semua data latih telah di presentasikan ke dalam jaringan lakukan perubahan bobot pada unit tersembunyi menggunakan nilai koreksi bobot hasil dari perhitungan menggunakan persamaan berikut.

$$
\begin{aligned}
& \Delta w_{i} \\
& =\left(\Delta w_{i}(1)+\Delta w_{i}(2)+\cdots\right. \\
& \left.+\Delta w_{i}(n)\right)
\end{aligned}
$$

Dimana :
$\Delta w_{i}=$ nilai koreksi bobot lapisan tersembunyi.

$n=$ jumlah data latih

13. lakukan perubahan bobot pada unit input menggunakan nilai koreksi bobot hasil dari perhitungan menggunakan persamaan berikut.

$$
\begin{aligned}
& \Delta v_{i} \\
& =\left(\Delta v_{i}(1)+\Delta v_{i}(2)+\cdots\right. \\
& \left.+\Delta v_{i}(n)\right)
\end{aligned}
$$

Dimana :

$\Delta v_{i}=$ nilai koreksi bobot lapisan input.

$n=$ jumlah data latih

Seperti yang dapat dilihat pada tahapan proses diatas, pelatihan Offline mendata nilai perubahan bobot pada setiap data latih. Setelah semua data latih telah dipresentasikan maka nilai perubahan bobot pada setiap data latih dijumlahkan untuk memperoleh nilai perubahan bobot baru yang digunakan untuk proses perubahan bobot. Berikut diagram alir dari proses pelatihan Offline.

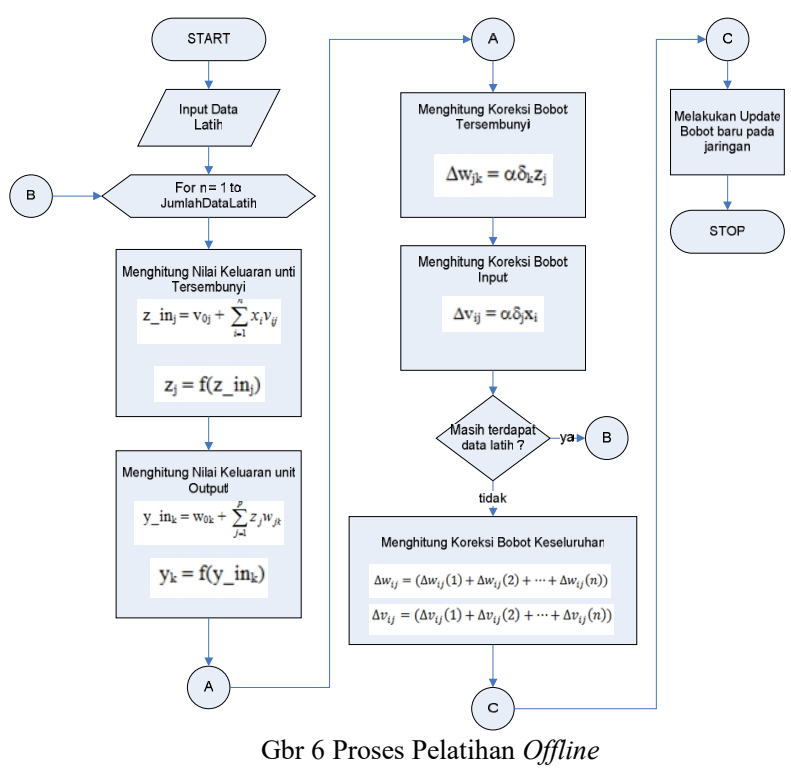

B. Analisis Proses PelatihanOnline

Pelatihan Online merupakan pelatihan jaringan saraf tiruan yang menganut konsep linear atau stochastic. Secara garis besar tahapan pelatihan pada jenis pelatihan Online dapat dijabarkan sebagai berikut.

1. Baca nilai input dari data latih $\mathrm{ke}-\mathrm{n}$.

2. Teruskan nilai input ke unit input.

3. Teruskan nilai input yang diterima oleh unit input ke unit tersembunyi atau hidden. 
4. Hitung nilai keluaran dari unit tersembunyi menggunakan nilai sinyal input terbobot menggunakan persamaan 2.2 dan melakukan perhitungan fungsi aktivasi untuk memperoleh nilai keluaran dari unit tersembunyi menggunakan persamaan 2.3.

5. Teruskan nilai keluaran dari unit tersembunyi ke unit output.

6. Hitung nilai keluaran dari unit output dengan menghitung nilai sinyal keluaran unit keluaran terbobot menggunakan persamaan 2.3 yang kemudian diikuti dengan menghitung nilai output menggunakan fungsi aktivasi menggunakan persamaan 2.4 .

7. Hitung galat error untuk data latih $\mathrm{ke}-\mathrm{n}$ menggunakan persamaan 2.5 .

8. Hitung koreksi untuk tiap bobot pada lapisan tersembunyi menggunakan persamaan 2.6.

9. Lakukan update bobot pada lapisan tersembunyi menggunakan persamaan 2.11 .

10. Hitung galat error pada unit tersembunyi menggunakan persamaan 2.9.

11. Hitung koreksi untuk tiap bobot pada lapisan input menggunakan persamaan 2.10 .

12. Lakukan update bobot pada lapisan input menggunakan persamaan 2.12

13. Lanjutkan tahap pelatihan untuk data latih $\mathrm{n}+1$.

Seperti yang dapat dilihat pada tahapan proses diatas, pelatihan Online tidak melakukan pendataan koreksi bobot yang disebabkan oleh setiap data latih. Nilai koreksi bobot yang diperoleh dari tiap data latih langsung diterapakan untuk melakukan perubahan bobot pada jaringan. Berikut diagram alir dari proses pelatihan Online.

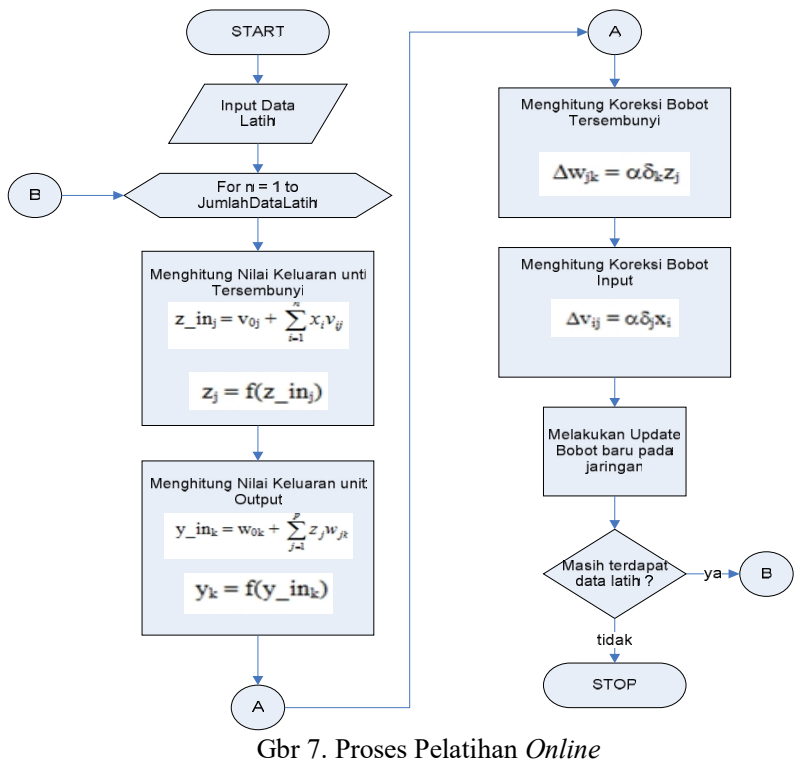

\section{HASIL DAN PEMBAHASAN}

A. Kerangka Kerja Pembuatan

Berikut kerangka kerja yang digunakan sebagai langkah-langkah dalam penyelesaian permasalahan diatas.

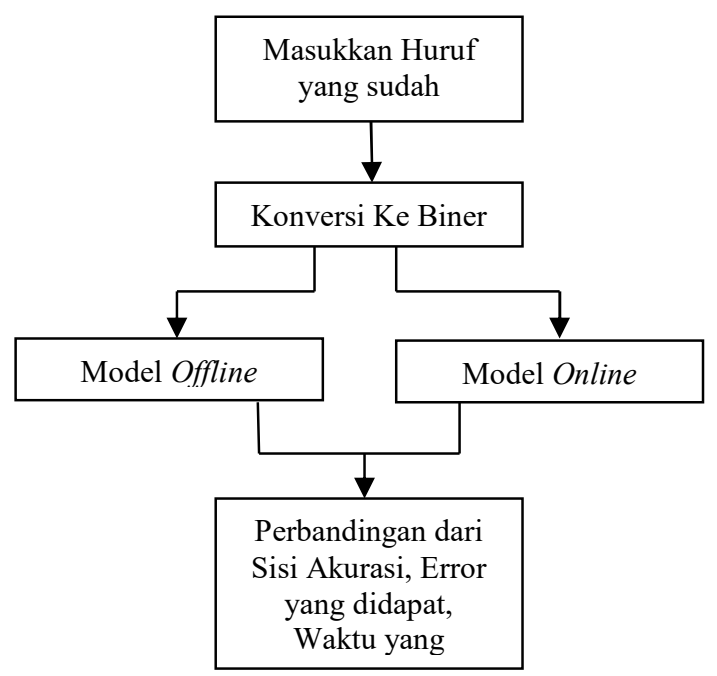

Gbr 8 Proses Kerangka Kerja

\section{B. Target Output Backpropagation}

Pada proses pelatihan harus ditentukan target output dari tiap karakter yang dipelajari. Berikut table target output pada tiap karakter. 
TABEL I

TARGET OUTPUT DATA PELATIHAN

\begin{tabular}{|c|c|c|}
\hline No. & Karakter & Target Output \\
\hline 1. & $\mathrm{~A}$ & $\begin{array}{llllll}0 & 0 & 0 & 0 & 0\end{array}$ \\
\hline 2. & B & $\begin{array}{llllll}0 & 0 & 0 & 0 & 1\end{array}$ \\
\hline 3. & $\mathrm{C}$ & 000010 \\
\hline 4. & $\mathrm{D}$ & 000011 \\
\hline 5. & $\mathrm{E}$ & 001000 \\
\hline 6. & $\mathrm{~F}$ & 000101 \\
\hline 7. & G & 0010110 \\
\hline 8. & $\mathrm{H}$ & 000111 \\
\hline 9. & I & 01000 \\
\hline 10. & $\mathrm{~J}$ & 010001 \\
\hline 11. & K & 0101010 \\
\hline 12. & $\mathrm{~L}$ & 001011 \\
\hline 13. & $\mathrm{M}$ & 011100 \\
\hline 14. & $\mathrm{~N}$ & 011101 \\
\hline 15. & $\mathrm{O}$ & 011110 \\
\hline 16. & $\mathrm{P}$ & 011111 \\
\hline 17. & Q & 10000 \\
\hline 18. & $\mathrm{R}$ & 10001 \\
\hline 19. & $\mathrm{~S}$ & 10010 \\
\hline 20. & $\mathrm{~T}$ & 10011 \\
\hline 21. & $\mathrm{U}$ & 10100 \\
\hline 22. & $\mathrm{~V}$ & 10101 \\
\hline 23. & W & 10110 \\
\hline 24. & $\mathrm{X}$ & 100111 \\
\hline 25. & $\mathrm{Y}$ & 11000 \\
\hline 26. & Z & 11001 \\
\hline
\end{tabular}

C. Parameter Jaringan Backpropagation

Pada jaringan Backpropagation terdapat beberapa parameter yang harus ditentukan untuk membentuk jaringan Backpropagationitu sendiri, berikut parameter - parameter yang akan digunakan pada penelitian ini.

1. Jumlah Node Input.

Sesuai dengan batasan masalah yang telah penulis uraikan mengenai ukuran piksel pada tiap karakter yaitu 10 x 10, maka jumlah node input pada jaringan harus dapat menampung tiap nilai dari tiap piksel karakter, sehingga jumlah node input yang digunakan adalah 100 Node.

2. Jumlah Node Output.

Karakter huruf terdiri dari karakter huruf besar dengan jumlah 26 karakter. Untuk itu harus disusun pola output biner yang dapat mengakomodasi jumlah karakter, sehingga digunakan jumlah node output sebanyak 5 node, dimana $2 \wedge 5$ adalah 32 sehingga dengan menggunakan 5 node akan memberikan kemungkinan 32 nilai keluaran berbeda yang mana sudah lebih dari cukup untuk mengakomodasi 26 karakter yang digunakan pada penelitian ini.
3. Jumlah Node Hidden.

Jumlah node hidden dapat dikalkulasikan sebagai berikut.

$\mathrm{NH}=\left(\frac{2}{3} x\right)+O=(2 / 3 * 100)+5=72$ Hiden Node.

D. Hasil Rancangan

Rancangan yang dibentuk dapat dilihat pada gambar dibawah ini:

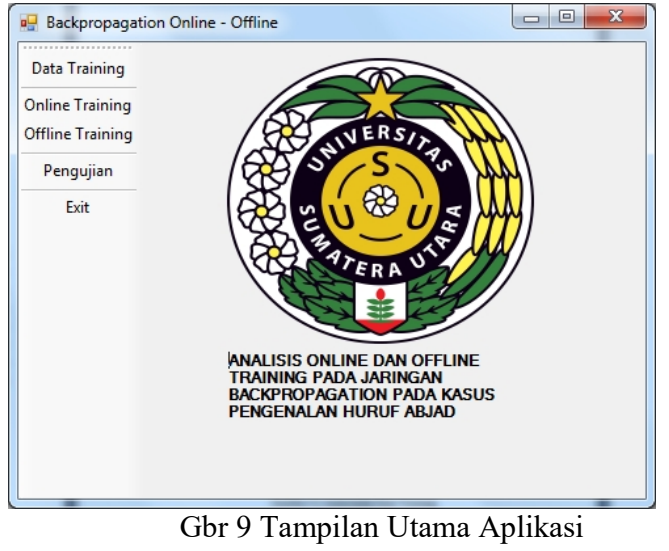

Aplikasi yang dibangun memiliki beberapa fitur utama yaitu pelatihan jaringan saraf tiruan Backpropagation terhadap data karakter dan kemudian identifikasi. Seperti yang telah dijelaskan sebelumnya, aplikasi yang dibangun merupakan alat bantu untuk meneliti kinerja jaringan dan bukanlah output utama dari penelitian ini. Untuk mengakomodasi kebutuhan akan pelatihan dan identifikasi terhadap karakter pada citra digital maka aplikasi dilengkapi dengan beberapa antarmuka seperti antarmuka data training yang dapat dilihat pada gambar berikut.

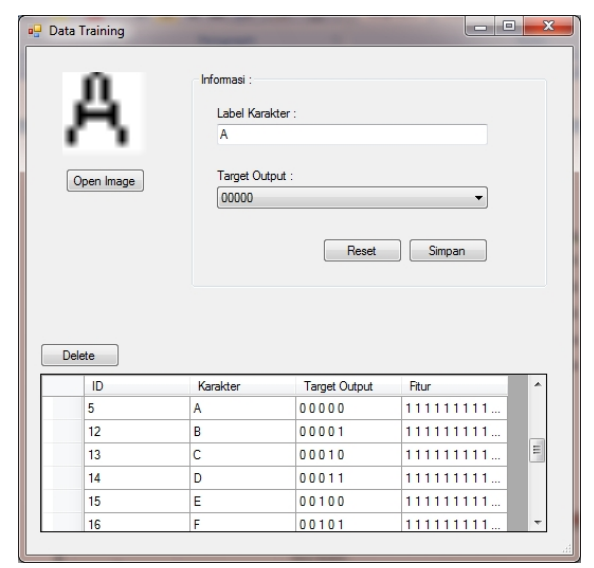

Gbr 10 Antarmuka Data Training

Antarmuka data training seperti yang terlihat pada gambar 10 memiliki beberapa fungsi yang dapat digunakan untuk melakukan penambahan dan penghapusan data latih yang digunakan untuk melatih jaringan saraf tiruan Backpropagation 
sebelum jaringan bacpropagation tersebut dapat digunakan untuk proses identifikasi atau pengenalan.

\section{E. Analisis dan Pengujian}

Analisis yang dilakukan pada penelitian ini adalah analisis terhadap kinerja jaringan saraf tiruan Backpropagation menggunakan pelatihan yang berbeda yaitu Online dan Offline training. Untuk dapat melakukan analisis terhadap jaringan saraf Backpropagation tersebut maka akan dilakukan pengujian terhadap jaringan Backpropagation yang dibangun. Parameter parameter dan data yang diperlukan oleh kegiatan pengujian pertama sekali harus ditentukan dan disiapkan seperti data karakter, parameter tingkat pembelajaran, bobot dan lain sebagainya.

Jaringan saraf tiruan Backpropagation memiliki arsitektur jaringan yang tetap sehingga diperlukan pengaturan konfigurasi dan penentuan parameter dalam membangun jaringan saraf tiruan Backpropagation sebelum dapat digunakan.jaringan saraf Backpropagation yang digunakan pada penelitian ini memiliki arsitektur sebagai berikut :

a. Jumlah unit input : 100 unit.

b. Jumlah unit tersembunyi (hidden node) : 60 unit.

c. Jumlah unit output : 6 unit.

Penggunaan jumlah unit input dengan jumlah 100 unit bertujuan untuk dapat mengakomodasi citra karakter yang berukuran 10 x 10 piksel, dimana citra dengan ukuran $10 \times 10$ piksel memiliki total piksel berjumlah 100 piksel sehingga diperlukan 100 unit input untuk dapat menerima nilai dari piksel dari citra karakter yang digunakan. Jumlah unit tersembunyi dipilih sebanyak 60 unit dengan mempertimbangkan bahwa jumlah unit tersembunyi harus diantara jumlah unit input dan jumlah unit keluaran. Unit output atau unit keluaran menggunakan 6 unit untuk dapat mengakomodasi rentang target karakter yang digunakan yaitu berjumlah 26 karakter.

Pengujian akan dilakukan secara bertahap yang mana setiap tahap akan menggunakan jumlah data karakter yang berbeda - beda. Secara garis besar pengujian yang akan dilakukan pada penelitian ini terdiri dari 5 pengujian yaitu pengujian A dengan menggunakan jumlah data pelatihan sebanyak dua data, pengujian $\mathrm{B}$ dengan menggunakan jumlah data pelatihan sebanyak 10 buah data, pengujian $\mathrm{C}$ dengan menggunakan jumlah data pelatihan sebanyak 26 buah data.
F. Pengujian A (Karakter A-B)

Pengujian A dilakukan dengan melakukan pelatihan pada jaringan saraf tiruan Backpropagation menggunakan dua data latih yaitu karakter A dan B. Pelatihan pada pengujian A akan dilakukan sebanyak dua pelatihan yaitu pelatihan Online dan pelatihan Offline. Proses pelatihan pada jaringan saraf tiruan Backpropagation pada pengujian ini menggunakan parameter pelatihan sebagai berikut.

a. Maksimum Epoch : 5000

b. Alpha (Tingkat Pembelajaran) : 0.5

c. Minimum Error / Goal : 0.001

Proses pelatihan dilakukan menggunakan aplikasi yang telah dikembangkan dengan menggunakan data latih citra karakter yang telah disiapkan pada bagian sebelumnya. Proses pelatihan dapat dilihat pada gambar 11 dan gambar 12 berikut.

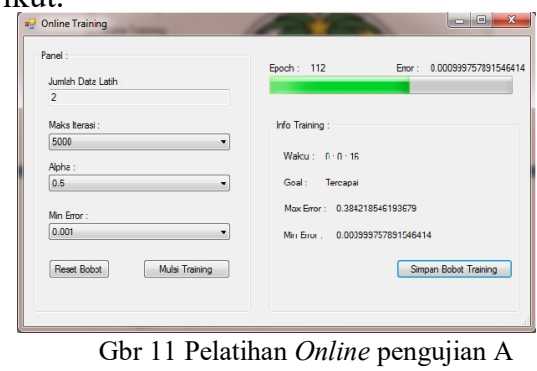

Pelatihan Online pada pengujian A seperti yang terlihat pada gambar 11 mampu mencapai goal atau target minimum error pada epoch ke 112 . Statistik memperlihatkan pelatihan Onlinemembutuhkan waktu 16 detik dalam proses pelatihannya.

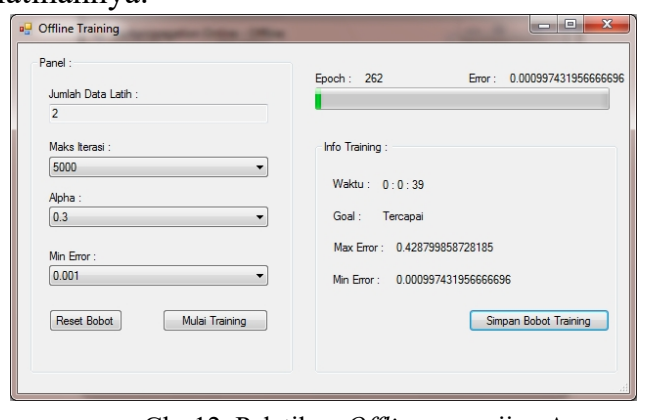

Gbr 12 Pelatihan Offline pengujian A

Pelatihan Offline pada pengujian A seperti yang terlihat pada gambar 11 mampu mencapai goal atau target minimum error pada epoch ke 262. Statistik memperlihatkan pelatihan Offline membutuhkan waktu 39 detik dalam proses pelatihannya. Berikut grafik dari error komparatif pada pengujian A. 


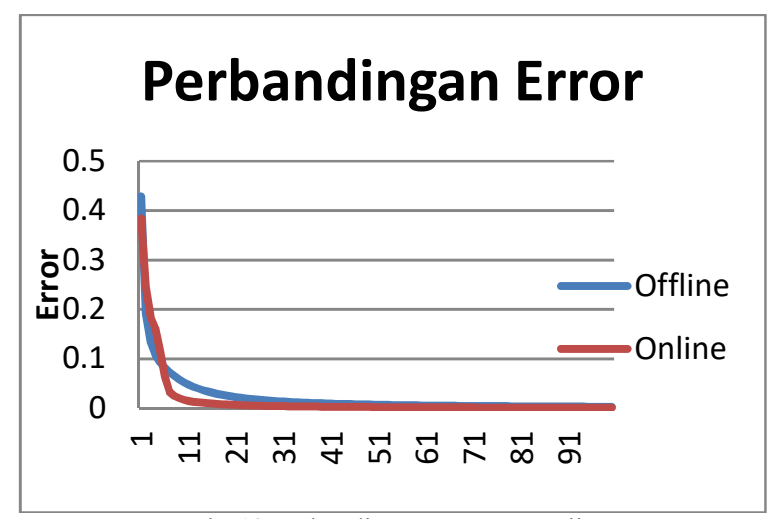

Gbr 13 Perbandingan Error Pengujian A

\section{G. Pengujian A (Karakter A-J)}

Pengujian B dilakukan dengan melakukan pelatihan pada jaringan saraf tiruan Backpropagation menggunakan sepuluh data latih yaitu karakter A sampai J. Pelatihan pada pengujian B akan dilakukan sebanyak dua pelatihan yaitu pelatihan Online dan pelatihan Offline. Proses pelatihan pada jaringan saraf tiruan Backpropagation pada pengujian ini menggunakan parameter pelatihan sebagai berikut.

a. Maksimum Epoch : 5000

b. Alpha (Tingkat Pembelajaran) : 0.5

c. Minimum Error / Goal : 0.001

Proses pelatihan dilakukan menggunakan aplikasi yang telah dikembangkan dengan menggunakan data latih citra karakter yang telah disiapkan pada bagian sebelumnya. Proses pelatihan dapat dilihat pada gambar 14 dan gambar 15 berikut.

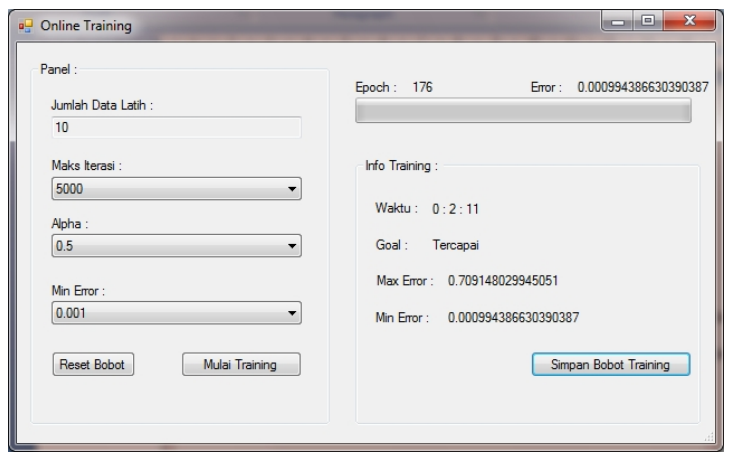

Gbr 14 Pelatihan Online pengujian B

Pelatihan Online pada pengujian B seperti yang terlihat pada gambar 14 mampu mencapai goal atau target minimum error pada epoch ke 176. Statistik memperlihatkan pelatihan Online membutuhkan waktu 2 menit 11 detik dalam proses pelatihannya.

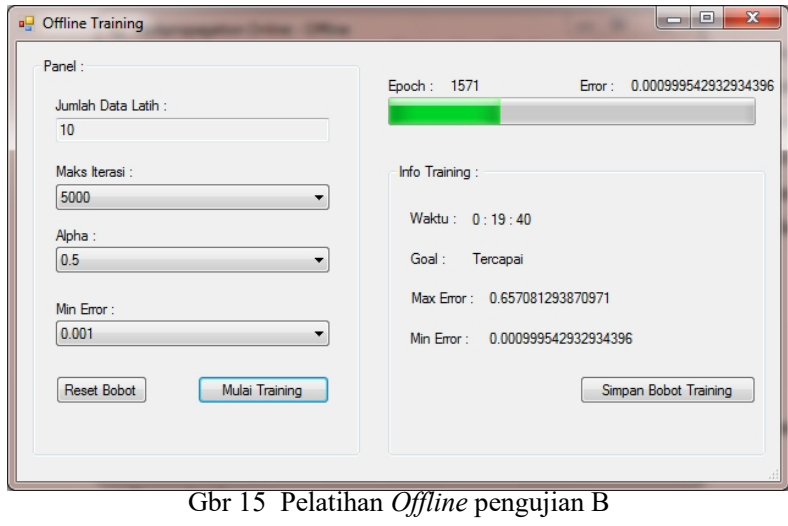

Pelatihan Offline pada pengujian B seperti yang terlihat pada gambar 15 mampu mencapai goal atau target minimum error pada epoch ke 1571. Statistik memperlihatkan pelatihan Offline membutuhkan waktu 19 menit 40 detik dalam proses pelatihannya. Berikut grafik dari error komparatif pada pengujian B.

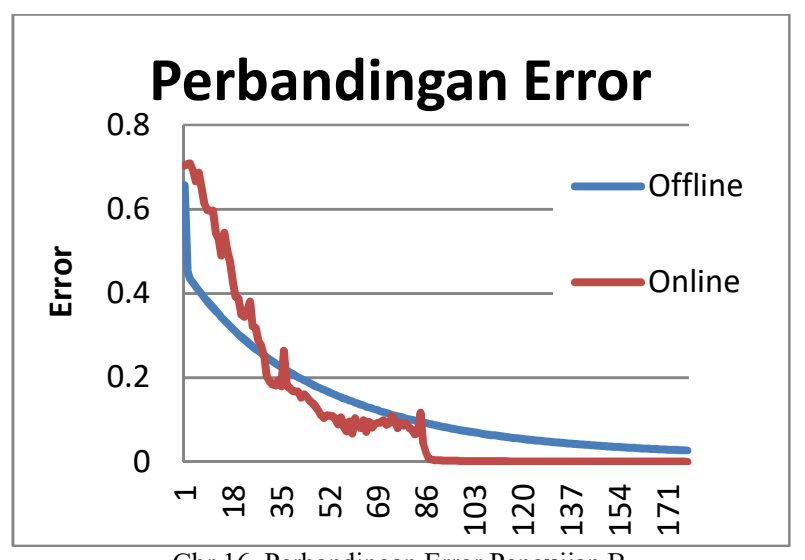

Gbr 16 Perbandingan Error Pengujian B

H. Pengujian A (Karakter A-Z)

Pengujian $\mathrm{C}$ dilakukan dengan melakukan pelatihan pada jaringan saraf tiruan Backpropagation menggunakan 26 data latih yaitu karakter A sampai Z. Pelatihan pada pengujian C akan dilakukan sebanyak dua pelatihan yaitu pelatihan Online dan pelatihan Offline. Proses pelatihan pada jaringan saraf tiruan Backpropagation pada pengujian ini menggunakan parameter pelatihan sebagai berikut.

a. Maksimum Epoch : 5000

b. Alpha (Tingkat Pembelajaran) : 0.5

c. Minimum Error / Goal : 0.001

Proses pelatihan dilakukan menggunakan aplikasi yang telah dikembangkan dengan menggunakan data latih citra karakter yang telah disiapkan pada bagian sebelumnya. Proses pelatihan dapat dilihat pada gambar 18 dan gambar 19 berikut. 


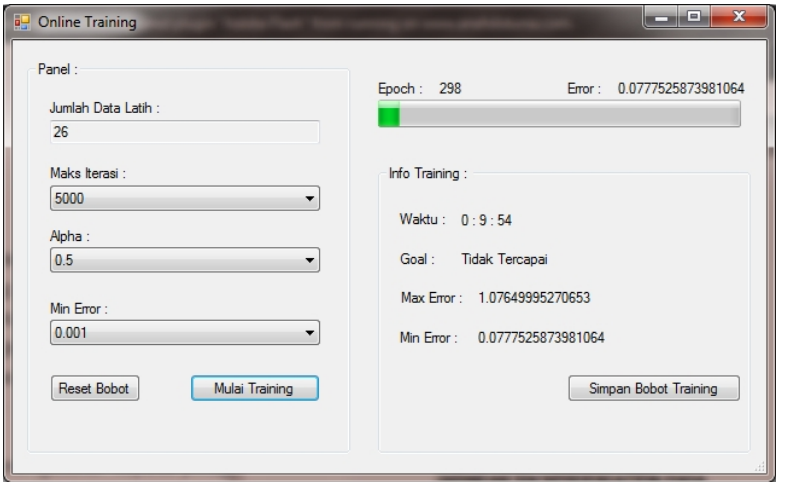

Gbr 17 Pelatihan Online pengujian C

Pelatihan Online pada pengujian B seperti yang terlihat pada gambar 18 tidak mampu mencapai goal atau target minimum error pada epoch ke 300. Statistik memperlihatkan pelatihan Online membutuhkan waktu 9 menit 54 detik dalam proses pelatihannya untuk mencapai 300 epoch.

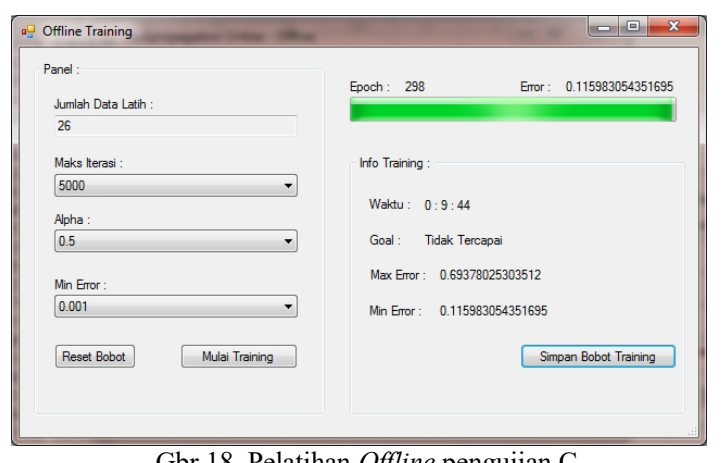

Gbr 18 Pelatihan Offline pengujian C

Pelatihan Offline pada pengujian C seperti yang terlihat pada gambar 19 tidak mampu mencapai goal atau target minimum error pada epoch ke 300. Statistik memperlihatkan pelatihan Offline membutuhkan waktu 9 menit 44 detik dalam proses pelatihannya. Berikut grafik dari error komparatif pada pengujian B.

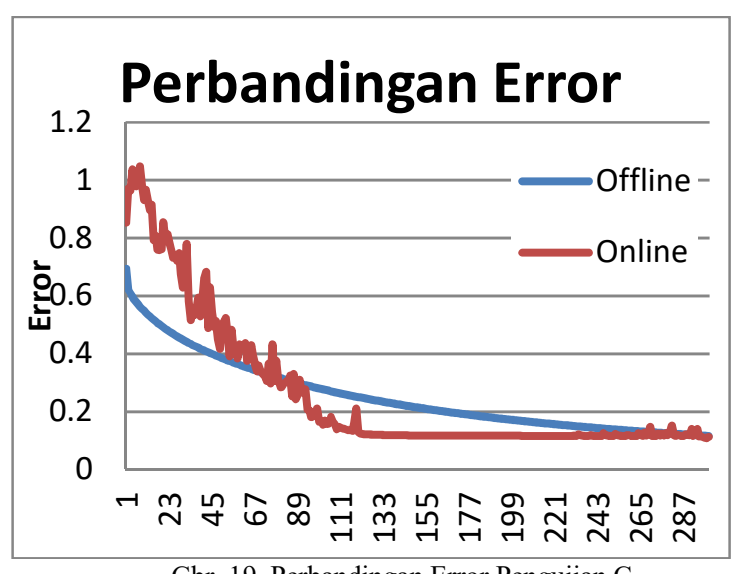

Gbr 19 Perbandingan Error Pengujian C

\section{Analisis Hasil Pengujian}

Pengujian yang telah dilakukan pada sub bab sebelumnya memberikan hasil statistik yang berbeda untuk tiap jenis pelatihan. Pada sub bab ini akan dilakukan analisis hasil pengujian serta pembahasan terhadap kinerja kedua jenis pelatihan jaringan saraf tiruan Backpropagation berdasarkan hasil analisis yang dilakukan. Berdasarkan pengujian yang telah dilakukan maka dapat diperoleh data kinerja dari kedua jenis pelatihan seperti yang terlihat pada tabel berikut.

TABEL II

HASIL PENGUJIAN PELATIHAN ONLINE

\begin{tabular}{|l|l|l|l|l|l|}
\hline No. & Pengujian & $\begin{array}{l}\text { Data } \\
\text { Latih }\end{array}$ & Target & $\begin{array}{l}\text { Epoch yang } \\
\text { dibutuhkan }\end{array}$ & Waktu \\
\hline 1. & $\begin{array}{l}\text { Pengujian } \\
\text { A }\end{array}$ & A-B & Tercapai & 112 & $16 \mathrm{D}$ \\
\hline 2. & $\begin{array}{l}\text { Pengujian } \\
\text { B }\end{array}$ & A-J & Tercapai & 176 & $\begin{array}{l}2 \quad \mathrm{M} \\
11 \mathrm{D}\end{array}$ \\
\hline 3. & $\begin{array}{l}\text { Pengujian } \\
\text { C }\end{array}$ & A-Z & Tidak & 300 & $\begin{array}{l}9 \quad \mathrm{M} \\
54 \mathrm{D}\end{array}$ \\
\hline
\end{tabular}

TABEL III

HASIL PENGUJIAN PELATIHAN OFFLINE

\begin{tabular}{|l|l|l|l|l|l|}
\hline No. & Pengujian & $\begin{array}{l}\text { Data } \\
\text { Latih }\end{array}$ & Target & $\begin{array}{c}\text { Epoch } \\
\text { yang } \\
\text { dibutuhkan }\end{array}$ & Waktu \\
\hline 1. & $\begin{array}{l}\text { Pengujian } \\
\text { A }\end{array}$ & A-B & Tercapai & 262 & $39 \mathrm{D}$ \\
\hline 2. & $\begin{array}{l}\text { Pengujian } \\
\text { B }\end{array}$ & A-J & Tercapai & 1571 & $\begin{array}{l}19 \mathrm{M} \\
40 \mathrm{D}\end{array}$ \\
\hline 3. & $\begin{array}{l}\text { Pengujian } \\
\text { C }\end{array}$ & A-Z & Tidak & 300 & $\begin{array}{l}9 \quad \mathrm{M} \\
44 \mathrm{D}\end{array}$ \\
\hline
\end{tabular}

Berdasarkan hasil pengujian seperti yang dapat dilihat pada tabel 2 dan 3 diatas, dapat dilihat bahwa pelatihan jaringan Backpropagation menggunakan pelatihan Online memberikan kinerja yang jauh lebih baik dibandingkan dengan pelatihan Offline baik dari sisi waktu maupun epoch yang dibutuhkan untuk mencapai goal. Namun seiring bertambahnya jumlah data latih atau data training, pelatihan Online memperlihatkan pergerakan error yang semakin tidak stabil seiring bertambahnya jumlah training. Pelatihan menggunakan jaringan Offline memiliki pergerakan error lebih stabil dimana error menurun secara halus. Hal ini menunjukkan pelatihan Offline memberikan kestabilan yang cukup tinggi dan memiliki toleransi terhadap meningkatnya jumlah data training. 
[1] ALGORITHM FOR MLP AND APPLICATIONTO AN DENTIFICATION PROBLEM.Durban: Centre For Engineering Research,Technikon Natal.

[2] Baxes, \& Gregory, A. (1994). Digital Image Processing :Principles and Applications. New York: John Wiley \& Sons.

[3] Cheriet, M. (2007). Character Recognition System. Canada: John Willey \& Son.

[4] Duffner, S., \& Garcia, C. (2007). An Online Backpropagation Algorithm with Validation Error Based Adaptive Learning Rate. Cesson-Sevigne: Orange Labs.

[5] Hermawan, A. (2006). Jaringan Saraf Tiruan. Yogyakarta: Penerbit Andi.

[6] Istook, E. (2003). IMPROVED BACKPROPAGATION LEARNING IN NEURAL NETWORKS WITH WINDOWED MOMENTUM. International Journal of Neural Systems, vol. 12, No. $3 \& 4$.

[7] LeCun, Y. (1998). Efficient BackProp. New Jersey:Springer.

[8] Lemme, A. (2010). Efficient online learning of a nonnegative sparse autoencoder. Bielefeld: CoR-Lab.

[9] McClelland, J. (2013). Explorations in Parallel Distributed Processing: A Handbook of Models, Programs, and Exercises. Stanford.

[10] Muijrers, V. (2011). Training a Back-Propagation Network with Temporal Difference Learning and a database for the board game pente. Philedelphia: ECTS

[11] Parker, L. R. (2006). Notes on Multilayer, Feedforward Neural Networks. CS494/594: Projects in Machine Learning.

[12] Sha, D., \& Bajic, V. B. (2000). ON-LINE ADAPTIVE LEARNING RATE BP.

[13] Singh, G. (2012). Recognition of Handwritten Hindi Characters using Backpropagation Neural Network. International Journal of Computer Scienceand Information Technologies, Vol. 3.

[14] Sutoyo, T. (2009). Pengolahan Citra Digital. Yogyakarta: Penerbit Andi.

[15] Tiwari, R. R. (2013). HANDWRITTEN DIGIT RECOGNITION USING BACKPROPAGATION NEURAL NETWORK\& K-NEAREST NEIGHBOUR CLASSIFIER. International Journal of Electrical, Electronics and Data Communication, Vol. 1. 